\title{
シラバスについて
}

Syllabus

\section{三上隆 ${ }^{* 1}$ \\ Takashi MIKAMI}

大学を取りまく環境は，18歳人口の減少，大学進学 率の増大とそれによる入学生の学力低下など大きく変 化してきている.この変化は, 我々に大学は社会的ニー ズのうえで存在することを常にそして強く意識するこ とを要求し，またこれまでの大学教育の在り方を社会 や学生のニーズに合わせた展開を求めるものである.

従来, 大学の教育においては, 教える内容, 教え方, 成績の評価などは, 担当教員の裁量に任されていたと いっても過言ではない. しかし, 今日の大学は, 社会 的存在理由が問われ, 説明責任が求められ, また教員 も自らの社会的責任を求められている. 学部の科目 (講 義・演習）は, 学部の教育理念・目的に沿って存在し, 教員はその理念・目的を達成する内容・方法で教育を 行うことが要求される. 評価基準は, 社会のニーズ, 学部の理念に求められ, これに適合したカリキュラム 内容に基づく教育の展開が求められる。 そして，カリ キュラムを構成する科目の目標, 内容・方法, 評価方 法などはシラバスとして表現される.

したがって，シラバスは，科目の設計図とも言える もので，そこに記述された流れにそって授業を展開す ることになる，教育は，学生と教員の共同作業である とよくいわれるように, シラバスは, 学生にとっても, 教員にとっても，重要な設計図であり，シラバスの整 備・改善は常に心掛けなければならない。

さて，筆者の勤務する北海道大学では，全国の大学 と同様に, ファカルティ・ディベロップメント（FD） などを通して, シラバスの重要性を強調し，その記載 内容・方法についての改善を行ってきている. また平 成11年前期より, シラバスの設問を含む「授業アンケー 卜」を学生に対して実施している。 その結果は平成 16 年後期・平成17年前期分まで, 北海道大学ホームペー ジ上に公開されている。ここでは，アンケートの集計 結果から, シラバスの内容に直接関係する 2 つ設問, (1)「シラバスは, 授業の目標, 内容, 評価方法を明快 に示していた」拉よび(2)「授業は体系的に行われてい た」に着目し，その結果（平均点）に基づき, シラバ スの改善点に考察を加えてみたい，なお，北海道大学

平成 19 年 5 月 14 日受付

$※ 1$ 北海道大学大学院工学研究科
のシラバスの記載内容は各学部で異なるが, 工学部専 門教育のシラバスには, 種別 (講義または演習) ・単 位数, 担当者, キーワードなどの他に,「主題と目標」, 「授業計画 (項目 (回数) と内容説明)」および「評価・ 教材・受講条件」が記載されている。 また「授業アン ケート」は, 各設問について, 「5, 4, 3, 2, 1」の 評点を 1 つ選んで○を付けてもらうもので, 評点は順 に，「強くそう思う，そう思う，どちらともいえない， そうは思わない，強くそう思わない」に対応する。 し たがって評点 3 は普通である。

平成11年前期， 12 年前期， 12 年後期と 13 年前期， 13 年後期と 14 年前期， 14 年後期と 15 年前期， 15 年後期と 16 年前期, 16 年後期と 17 年前期の計 7 回の集計結果は, 設問(1については順に，3.37，3.53，3.58，3.62，3.67， 3.69，3.71，設問(2については順に，3.63，3.78，3.82, $3.84,3.86,3.87,3.89,2$ つの設問の平均は, $3.50,3.65$, 3.70, 3.73, 3.77, 3.78, 3.81である.

結果は, いずれも平均以上であり, 評価点は年々増 加しているが， シラバス担当教員を中心にシラバスの 改善に努めてきているにしては, 特に設問(1)増加率 は, 筆者が予想していたものより小さい. この理由に は, 学生がシラバスを十分に読んだかどうか, シラバ スの意義・有用性, 重要性を意識・理解したことがな いのではないかなど, 学生側の問題も考えられるが, 以下に，教員側が留意すべき事項を列挙する.

1) 教員は, シラバスの意義・役割, 使用方法につい て, 学生に適切に教えているかどうか.

2 ） シラバスは, 入学直後に学生に配布されるもので ある。したがって, 高校生でも理解できるような 言葉, 表現で記載されているかどうか.

3 ) ほとんどの教員は, 目標を学生が主語になる表現 （例えば,「○○を学ぶ」,「○○を予測できる」) で記述しているが，抽象的な記述になりすぎてい ないか, 学生は, より具体的な目標の説明を求め ていないか.

4 ）どの程度の記載をもって必要かつ十分な記載をし たのかについて, 教員間での共通認識があるのか. 教員は, シラバスの重要性を理解していても, そ れを活用していないのでないか.

5 ）学生の授業意欲を引き出す評価法となっている 
か，適正な授業の到達目標が設定され，達成度が 適正に評価され成績に反映されているか.

今後ますます大学が開放され，国際化が進み，他大 学や海外の大学との「単位互換」が進んでいく状況を 考えると，一般的な授業の計画と評価が求められる. そのためにも, 大学間で, 共通のシラバスの表現法を
採用する必要があり, 今後は, 大学の枠を越えた「大 学間レベルでの検討」が必要かもしれない.

以上, 他大学のシラバスの調査・比較を行うことな しに，筆者の独断で記述した．何か役立つものがあれ ば幸いである。 